\title{
NAGYDOBRONY ÉS A NAGYDOBRONYI VADVÉDELMI REZERVÁTUM (KÁRPÁTALJA) FÖLDRAJZINÉV-TÁRÁNAK ELKÉSZÍTÉSE ÉS ÁBRÁZOLÁSA TÖRTÉNETI TÉRKÉPEK ALAPJÁN
}

\author{
KOHUT ERZSÉBET - BENEDEK ANETT - HADNAGY ISTVÁN \\ GEOINFORMATIC ANALYSIS AND \\ REPRESENTATION OF THE GEOGRAPHICAL NAMES OF VELYKA DOBRON \\ AND THE WILDLIFE RESERVE OF \\ VELYKA DOBRON (TRANSCARPATHIA) BASED ON HISTORICAL MAPS
}

\begin{abstract}
The Wildlife Reserve of Velyka Dobron - which is located next to the village of Velyka Dobron (Hungarian: Nagydobrony), the fourth most populous Hungarian community in Transcarpathiais the third-largest protected reserve of national importance in the country. We used a Geographic Information System to process and map the historical geographical place names of the settlement and the protected area (pieces of land within the cadastral boundaries but located either outside the settlement boundary or on its outskirts) based on the 1st, 2nd and 3rd military surveys, a cadastral map dating back to 1865 and the documents available in the Beregszász branch of the State Archives of Transcarpathian Oblast (fonds 125, description 6, file 344), as well as literary materials. As a result, a database comprising a list of 57 place names of the area was compiled. Likewise, a map of the pieces of land within the former cadastral boundaries and in the Nagydobron' Wildlife Reserve was made. Analysis of forest area and land use changes showed that 16 pieces of land within the cadastral boundaries, but located either outside the settlement boundary or on its outskirts, have completely lost their former nature and as a result became part of the inner area of the settlement. Consequently, the compiled database and maps may help to specify the location of the ongoing research and clarify the accurate place of the earlier studies.
\end{abstract}

Keywords: geographical gazetteer, cadastral map, Velyka Dobron, Wildlife Reserve of Velyka Dobron (WRVD), Transcarpathia

\section{Bevezetés}

A névtannak, mind a személynév, mind a földrajzi név kutatásának, a névtárak létrehozásának - a Kárpát-medencén belül is - hatalmas irodalma van (LőRINCZE L. 1947; KISS L. 1980; JuHÁsz D. 1988; BíRó F. 1997; Kiss L. 1999; FARAGó I. 2005; SEBESTYÉn Zs. 2010; GÁBRIS GY. 2019), amelyet a természettudomány nem alkalmaz kellőképpen. A hagyományos földrajzi nevek, tájnevek, helynevek nagy része több száz éves múltra tekint vissza (FARAGÓ I. 2016). Eredetük legtöbb esetben természetes, múvi hatásoktól mentes, az egyes tájak, települések és határrészek természeti, gazdálkodási, történeti jegyei alapján keletkeztek. Éppen ezért az ilyen névtárak segítségével, a névváltozások nyomon követésén keresztül sokféle információ szerezhető be, amit több tudományterület: földrajz, történeti ökológia, természetvédelem, erdőgazdálkodás, környezeti nevelés, névtörténet, tájtörténet, néprajz stb. is felhasználhat. Emellett nem elhanyagolható szempont az sem, hogy a hagyományos helynevek, határ- és dűlőnevek eredeti helyükön való megórzése épp annyira fontos, mint a természeti értékek, múemlékek megvédése, a folklór értékeinek ápolása (GÁBRIEL A. 1991).

A helynevek gyújtésével Kárpátalján is leginkább történészek (LEHOCZKY T. 19811882/1996; Botlik J.-DupKa Gy. 1993), nyelvészek (Bíró A. 1993; Beregszászi A. 1998; MizSer L. 2004; KovÁCs A. 2008; Sebestyén Zs. 2003, 2008a, b, 2015, 2016a, b) 
és geográfusok (Molnár J.-MolnáR D. I. 2005; MolnÁR D. I. 2014) foglalkoznak. Nagydobrony és környéke földrajzi neveirôl a legtöbb információt SEBESTYÉN Zs. (2003, 2008a, 2010, 2015) és MiZSER L. (1995, 1996, 2004) munkáiban találjuk. SEBESTYÉN Zs. (2003, 2008a) Kárpátalja településeinek helyneveivel foglalkozott, 476 település helynevét közli a Kárpátaljai Területi Âllami Levéltár beregszászi fiókjában megtalálható kataszteri térképekről, birtokrészleti jegyzőkönyvekből, illetve határjárásokból származó adatok alapján. Ebben Nagydobronyra 1863-ból, 1865-ból és 1908-ból származó névanyagot közöl. Az 1865-ös névanyag kataszteri térképek alapján készült, míg az 1863-as és 1908-as adatok forrása birtokrészleti jegyzőkönyv. Valamennyi adat a 125. fond 1. opiszából a 661., 654., 662., 655., 656. számú iratcsomókból származik. Különös jelentőséggel bír Pesty Frigyes helységnévtára (1864-1865) is, amelyből Bereg megyei helységneveket MizSER L. (1995) adott közre magyarázatokkal. Az 1865-ben készült múben az akkor Nagydobrony határában megtalálható összesen 113 dúló és egyéb földrajzi név szerepel, a területre jellemző rövid leírásokkal. MIzSER L. (1966) a Nagydobrony határában folyó Latorca ősvízrajzával és ártéri gazdálkodásával foglalkozó munkájából is számos információt tudhatunk meg a környék földrajzi, határ- és dúlőneveiról.

A munka célja a kárpátaljai Nagydobrony község és a Nagydobronyi Vadvédelmi Rezervátum (NVR) területéhez tartozó földrajzi, határ-, valamint dúlőnevek egységesített névtárának és digitalizált térképének elkészítése. Jelen tanulmány nem névtudományi jellegű munka; bár hasonló módszereket alkalmaz, de nem célja a létrehozott névadattár nyelvészeti vizsgálata. A munkával új utat keresünk, olyan névtárat készítünk, amely Kárpátalja egyik legnagyobb magyarlakta települése (Molnár J.-MolnÁR D. I. 2005), Nagydobrony és a mellette elterülő NVR helynévanyagát gyújti össze és térképen ábrázolja. Ezt többek között az is indokolja, hogy mind a helybéli (KoHUT E. et al. 2006, 2007; KISH, R. et al. 2006, 2009; Prots, B. 2010; Kohut, E. 2013; Kolozsvári, I. et al.2015a, b; SzAnYi Sz. et al. 2015a, b, c, 2016; Demeter, L. 2013, 2016; SheVera, M. et al. 2017; KoHUt E. et al. 2017, 2019), mind a magyarországi (MAGURA, T. et al. 1997; DELI I.-SüMEGi P. 1999; MAGURA, T.-KÖDÖвÖCz, V. 2005) és más határon túli (NovÁK, P. et al. 2017) kutatók figyelme ráirányult Kárpátalja alföldi régiójának természeti értékeire. Segítségével megvalósítható a már itt folyó vagy elvégzett kutatások helyének (táj- és dűlőneveinek) pontosítása, illetve egyértelműsítése.

További megerősítést találtunk UNGVÁRY R. (2016) tanulmányában, amelyben a szerző rávilágít arra, hogy az interneten elérhető magyar nemzeti névtár és névtárak kialakításával a határon túli magyar nyelvhasználat jelentős kulturális, nem utolsósorban nyelvpolitikai támaszt kap. Megállapítja, hogy jelenleg nincs átjárás sem a földrajzi nevekkel foglalkozó térképészeti, sem a nevekkel foglalkozó nyelvészeti szakterületek között. Mi ezt az átjárhatóságot ki szeretnénk terjeszteni más tudományterületek irányába is. Reményeink szerint az elkészült munka eredményeit alkalmazni tudják majd nemcsak a NVR és környékét kutató nyelvészek, természettudósok és környezeti nevelők is.

\section{Módszertani háttér}

\section{A vizsgált terület bemutatása}

Nagydobrony Árpád-kori település, 1248-tól Dobron, Dobrun néven kerül említésre. A falu életében mindig fontos szerepet játszott az erdő. Erre utalnak a történeti adatok is (LEHOCZKY, T. 1881-1882/1996). 1638-ban Melith György törvénykezett a csongori (csomonyai) és nagydobronyi erdők határával kapcsolatban. Később Rákóczi György is vizsgálatot indított az erdők használatát illetôen (MóRICz K. 1993). Ezen erdők maradványai a község 
határában most is fellelhetők. A Dobrony helységnév magyar eredetű, puszta személynévből keletkezett magyar névadással. Az alapjául szolgáló személynév szláv, valószínúleg a szláv dobъ „tölgy” származéka (SEBESTYÉN Zs. 2008a). A település és környéke az 1919-es Párizs környéki békeszerződésig Magyarország része volt, azon belül Bereg megyéhez tartozott. A csehszlovák időben (1920-1938/1939, 1944-1945) a falu neve Velká Dobron volt (BоTLIK J.-DuPKA Gy. 1993). A szovjet közigazgatás (1945-1991) az Ungvári járásba sorolta, az 1960-as években egy ideig a Perecsenyi járás részét képezte (MóRICZ K. 1993). Ma használt neve a Nagydobrony, ukrán nyelven Велика Добронь. Kárpátalja negyedik legnépesebb, több mint 5000 főt számláló magyar közösségét foglalja magába (Molnár J.-Molnár D. I. 2005). Az Ukrajnában 2020 júliusában jóváhagyott közigazgatási reform alapján az Ungvári járáshoz tartozik, azon belül a Nagydobronyi kistérség (hromada) része (Molnár D. I.-Tóth-Orosz E. 2020).

A vizsgálatunk másik szegmensét képező Nagydobronyi Vadvédelmi Rezervátum (ukránul: Загальнозоологічний заказник загальнодержавного значення „Великодоброньський”) Kárpátalja harmadik legnagyobb országos jelentőségű védett területe 1736 ha $(17,4$ km²) kiterjedésú. A rezervátumot az Ukrán Szovjet Szocialista Köztársaság Miniszteri Tanácsának 1974. évi határozata alapján létesítették. Eredeti rendeltetése az itt fészkelő madarak és vadak élőhelyeinek védelme. Ukrajna Ökológiai és Természeti Erőforrások Minisztériumának 2012-es rendelete megerősíti a vadvédelmi (zoológiai) rezervátum státuszát (KMÁAÖTESZ 2020). 2009-ben a területén kijelölték a Tiszamelléki (Pritiszjánszkij) Tájvédelmi Park (ukránul: Притисянський регіональний ландшафтний парк) latorcai szakaszát is (KISH, R. et al. 2009). A NVR jogilag az Ungvári Állami Erdőgazdasághoz, azon belül a Nagydobronyi Erdészethez tartozik. Négy részlegből áll (1.ábra): Kozup-

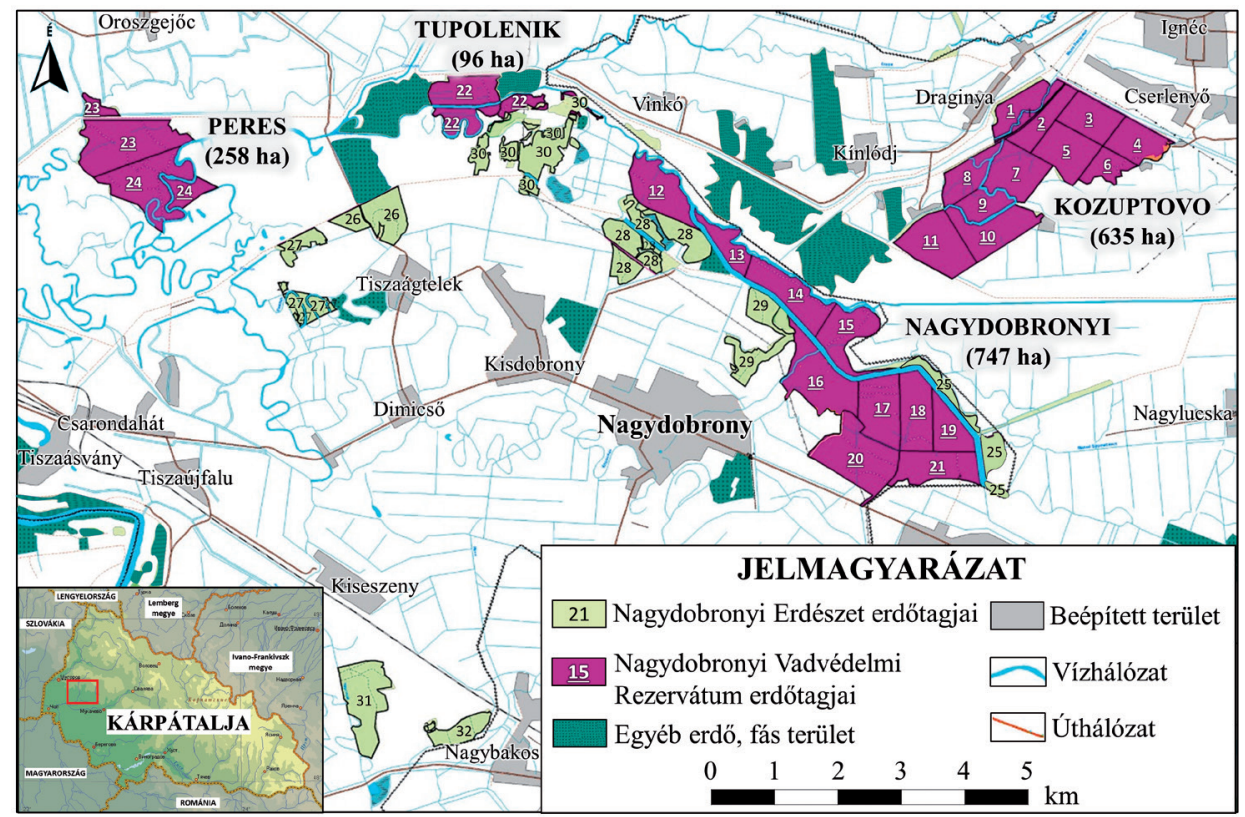

1. ábra A Nagydobronyi Vadvédelmi Rezervátum (NVR) részlegei és azok erdőtagjai (az Ungvári Állami Erdőgazdaság (2019) adatai alapján)

Figure 1 Parts and forest quarters of the Wildlife Reserve of Velyka Dobron (based on data from Uzhhorod State Forestry (2019)) 
tovo (635 ha), Nagydobronyi (747 ha), Tupolenik (96 ha) és Peres (258 ha). Az NVR részlegeiben összesen 24 erdőtagot különítenek el: a Kozuptovo részleg az 1-11., a Nagydobronyi a 12-21., a Tupolenik a 22., a Peres pedig a 23. és 24. számú erdőtagokból áll (1. ábra).

\section{A földrajzi nevek (határ-és dülónevek) egységesitett névtárának elkészítése}

Földrajzi neveknek az olyan tulajdonneveket tekintjük, amelyeket a földfelszín természetes (hegy, völgy, forrás, vízfolyás, tenger, táj stb.), illetve mesterséges (dűlő, csatorna, út, település, megye stb.) részleteinek azonosítására használnak (FARAGÓ I. 2016). A földrajzi nevek legnépesebb csoportját a határnevek vagy más néven határrésznevek alkotják. Határnéven a település kataszteri területén belül, nem a belterülethez tartozó földrajzi helyrészletet jelölő nevet értjük. A határneveket egy helység lakói adják településük külterületi részeinek azonosítására, ezért e nevek legtöbbször csak egy-egy település közigazgatási (kataszteri) határán belül helyezkedhetnek el (FARAGÓ I. 2016). Dúlő́n pedig az olyan mesterségesen kialakított, általában négyzetes alakú, mezsgyével határolt, általában mező- vagy erdőgazdasági múvelés alatt álló földdarabot értjük, amely a település külterületében, de kataszteri határán belül alakítottak ki a folyószabályozásokat követően és azt helyrajzi számmal láttak el (BíRó A. 1997). Ilyenformán a dúlő a határ, határrész szúkebb értelemben vett formája (LŐRINCZE L. 1947). A határ- és dűlőnevek tanúskodnak a határ régi természeti viszonyairól (pl. vízrajzáról, növényborítottságáról), az egykori múvelési formákról, a termesztett növényekről, földhasználati módokról, a birtokbavétel módjáról, a birtoklási formákról és azok változásáról és a környező egykori településekről, azok neveiről.

A földrajzi névanyag (határ- és dúlőnév) összeállításához az alábbi online elérhető (http:// arcanum.hu/hu/) és (http://mapire.eu/hu/) nyilvános térkép-adatbázisokat használtuk fel:

- Magyarország (1782-1785) első katonai felmérésének térképét ( $\mathrm{M}=1: 28800)$;

- Magyarország (1819-1869) második katonai felmérésének térképét ( $\mathrm{M}=1: 28$ 800);

- Magyarország (1869-1887) harmadik katonai felmérésének térképét $(M=1: 25000$ és $\mathrm{M}=1: 75000)$;

- Magyarország (1865) kataszteri térképét.

Az 1865-ös Kataszteri térképen szereplő neveket kiegészítettük a katonai felmérések térképein szereplő földrajzi nevekkel és összevetettük a levéltári dokumentumokkal. A dúlőnevekhez hozzárendeltük a Kárpátaljai Területi Állami Levéltár beregszászi fiókjában megtalálható iratanyag (125. fond, 6. opisz. 344. iratcsomó) alapján a helyrajzi számokat. A nevek írásában az említett térképeken szereplő írásmódot követtük. A község határában lévő, a kataszteri térképen névvel nem jelölt, de jól elkülöníthető területekhez is hozzáírtuk a helyrajzi számokat, ezt táblázatba rendeztük. A kapott névanyagot összevetettük SEBESTYÉN Zs. (2008a) névanyagával, illetve Pesty Frigyes Mizser L. (1995) által közreadott Bereg megyei helységnévtárával (1864-1865). Nagydobrony község 1985-ös kataszteri határain belül eső és a NVR-hoz tartozó erdő földrajzi neveit digitalizált térképen ábrázoltuk.

\section{Az adatok térinformatikai feldolgozása és térképi ábrázolása}

A történeti tájak és azok változásának vizsgálatában, tipizálásában az írott források mellett komoly szerepe lett a geoinformatikai (GIS) módszerek alkalmazásának. A különböző források adatbázisainak, történeti térképeinek digitalizálása és térinformatikai feldolgozása jelentősen kitágította a térbeli elemzések és ábrázolások lehetőségét és egyúttal a távérzékelési adatok (pl. légi- és ûrfelvételek) forrásként való bevonását is (MóGA J. et al. 2014; CsorbA P. et al. 2018). 
Nagydobrony és a NVR területe földrajzi részleteinek digitalizálását, majd a térképek elkészítését az ArcGis 10.1 térinformatikai szoftver segítségével végeztük el. Az online adatbázisból letöltött térképszelvényeket georeferáltuk, vetületbe illesztettük. A történelmi tájrészletek térképezését a vonalas objektumok (vízfolyás, határ, úthálózat, töltés) digitalizálásával kezdtük. Ezt követte a területtel rendelkező objektumok (erdők, dúlők, állóvizek, időszakosan vízzel borított területek) digitális ábrázolása. A dűlők és a különböző földhasználat alatt álló területek határait az 1865. évi kataszteri térkép és a levéltári helyrajzi számok alapján állapítottuk meg. A térképen a határrészeket és dűlőket számokkal jelöltük, ezek nevei a jelmagyarázatban szerepelnek. Az elkészült GIS attribútum-táblázatok és térképi shape-állományok a területen folyó további kutatások alapjai lehetnek.

\section{Eredmények}

Az I. katonai felmérés (1782-1785) térképének választott szelvényén jellemzően kevés földrajzi név szerepel Nagydobrony környékén. A két szomszédos település Kis Dobrony és Comonia (a mai Csongor) települések mellett Nagydobrony Nagy Dobra néven található meg. A település egy utcából áll, amelyen keresztülfolyik egy patak, a falu központjában egy kőtemplom van. A térképen szembetűnő a hatalmas összefüggő erdőtömb, amely északkeletről és délnyugatról körbezárja és határolja a települést. A folyónevek közül a Latorcza és Kerepez vízfolyásnevek olvashatók.

A II. katonai felmérés (1819-1869) térképén már szerepel a Nagydobrony falunév. Az előző térképhez képest sokkal részletgazdagabb és pontosabb a terület ábrázolása, több földrajzi név található. A térképet valószínúleg két rajzoló készítette, ez a lapok összeillesztésén és a térképrészletek színezésén is tapasztalható. Az összeillesztésnél eltérnek és felcserélődnek a folyónevek: a Grosse Latorcza a Kis Latorczával, a Kleine Latorcza a Nagy Latorczával folytatódik. A két rajzoló írásmódja is elkülöníthető. A folyók és patakok megnevezése mellett jól olvasható a Fluss (folyó) vagy a Bach (patak) szó. A jelkulcsot használva azt látjuk, hogy az elsőhöz képest a falu területe növekedett. A falu a Csólnakút $\mathrm{B}$ névvel jelölt patak két oldalán terül el, a központjában egy kőtemplom áll. A patakon három híd vezet át - bakhíd vagy faborítású híd; nem látható pontosan. Jól kivehető a vízszabályozást megelőző, kiterjedt vízrendszer és a folyóártér. A szabadon kanyargó Latorca mellékágrendszere részletesen van ábrázolva. A kivágaton a következő vízfolyások és állóvizek nevét találjuk: Nagy Latorcza, Csólnak-út (Csonok-út Bach is), Matzontza, Nagy Györtyös, Kis Györtyös, Nagy-Szabad-patak, Kis-Latorcza, Mosonca, Marton patak, Láb patak, Patakcsa Bach, Poroscsanyik, Borotsányék Györgyös, Fekete Tó, Horgas Tó. Ezek közül - a Latorca folyónév mellett - ma csak a Masonca név ismert a falubeliek körében. A falutól északkeletre elterülő, a NVR nagydobronyi részlegének legnagyobb részét alkotó akkori erdőtömb Kis Erdő nevén szerepel.

A III. katonai felmérés térképe (1869-1887) már részben a folyószabályozás utáni állapotokat rögzíti. A térkép fekete-fehér lenyomatos. Az erdő területe tovább csökkent. A falut keresztülszelő patak neve Hatracz-ra változott és összeköttetésben van a Latorcza Györgyos, Macsoncsa és Kerepecz patakokkal. A Kis erdő elnevezés az északkeleti egybefüggő erdőtömb Csomonyához (mai Csongorhoz) közelebb eső, kisebb területét jelöli. A nagyobb rész Felső erdőként szerepel. A vízfolyások nevein kívül számos dûlőnév vagy majorság neve is fel van tüntetve, ami a földhasználatra utal. A szántók nem különülnek el a rétektől és mezőktől, amelyek az összefüggő erdőtömböt bontják meg. A gyümölcsösök sem különülnek el. Pesty (1864-1865) leírásában a Vörös Gorondon gyümölcsös van. A térképen a terület neve Vörös Gorom, vonalkázással elkülönül az erdőtől és a vele érintkező mezőtől. 
A térképszelvényen olvasható földrajzi nevek: Felső erdő, Kis erdő, Katoszög, Mocsonka, Zucska, Kis gara, Szomogya, Vörös gorom, Daranyo, Tamas eger, Kerepeczi erdő, Also erdő. A folyó- és pataknevek közül a következőket találjuk a térképen: Str. Latorca, Hatracz patak, Maconca patak, N. eger, Száraz Latorca, Latorcai csatorna, Kerepecz patak, Szernye patak, Bara patak. Az eredeti nagy térképes ábrák megvannak és felhasználhatók a jövőbeni kutatások során. Nagydobrony és a NVR jelenkori elhelyezkedését és kiterjedését ábrázoltuk az egykori katonai felmérések térképein, ezek a nagy térképes ábrák rendelkezésre állnak és felhasználhatók a jövő́beni kutatások során.

A kataszteri térképen (1865) rögzítettek is már számos folyó és patak medrének szabályozásáról tanúskodnak. A községet és határrészeit átszövő folyó- és csatornahálózat nevei közül a Latorcza folyó, Latorcza ág, Hatrácz (az előző térképen Hatracz) patak, Mocsonka, Macsoncza patak, Daranyó csatorna, Magasparti csatorna, Kerepecz patak, Hatamsa, Kis patak, Zseje patak feliratokat találjuk meg, továbbá egy névvel nem, csak számmal ellátott csatornát: 3424 csatorna.

A digitalizált térképen (2. ábra) számmal jelölve, északról délre haladva feltüntettük a Nagydobrony 1865-ös kataszteri határain belül eső és a NVR területén található valamennyi határrészt és dúlőt. Továbbá kiemeltük Nagydobrony jelenkori lakott és beépített területét, a környező erdők jelenlegi kiterjedését, valamint a nagyfokú mederszabályozáson átesett vízhálózatot.

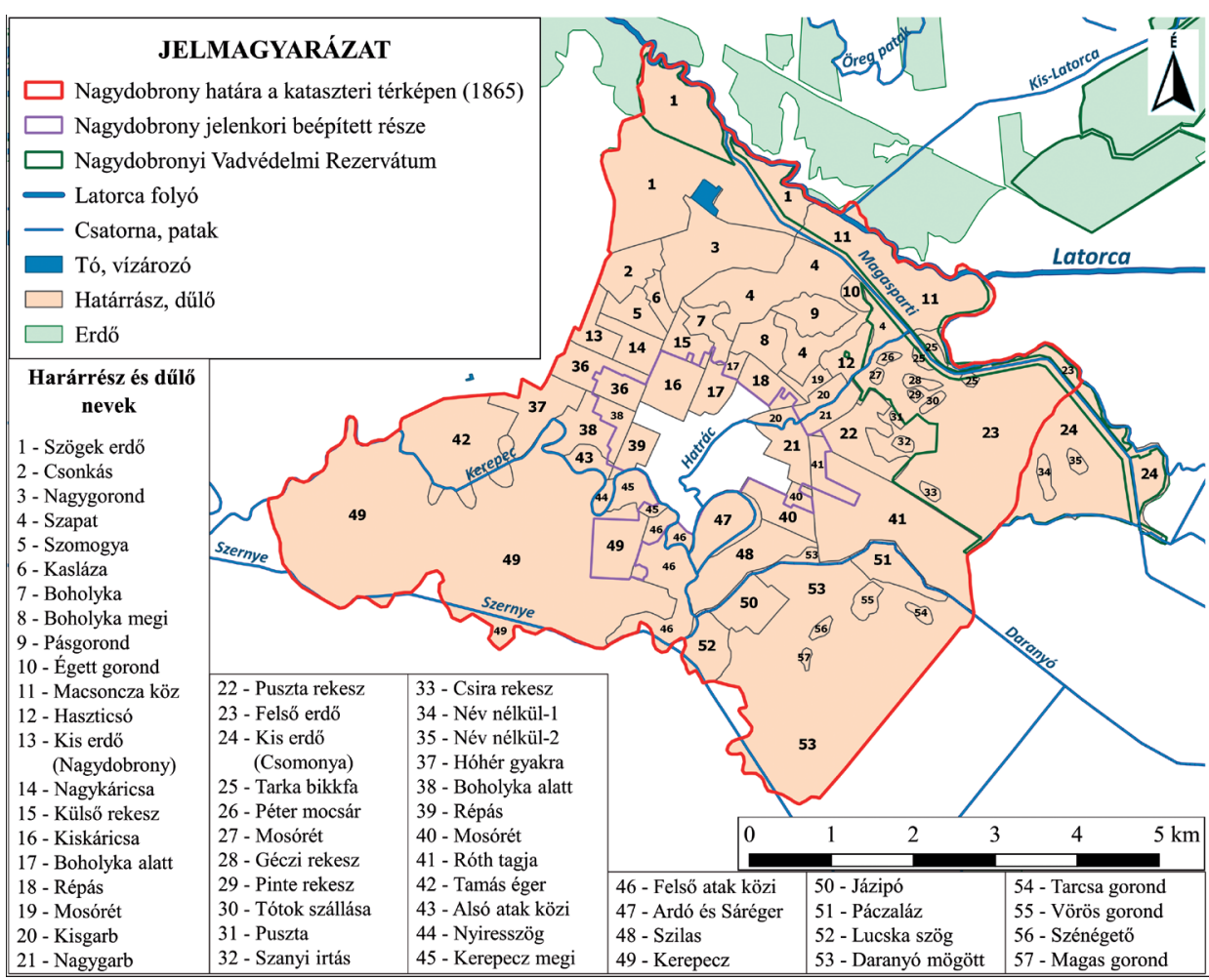

2. ábra Nagydobrony és a NVR földrajzi nevei (határ- és dúlónevei)

(Magyarország kataszteri térképe (1865) alapján)

Figure 2 Geographical names of Velyka Dobron and the WRVD

(based on the cadastral map of Hungary (1865)) 
Célkitűzésünknek megfelelően elkészítettük Nagydobrony község és a NVR területének egységesített földrajzinév-tárát. A dűlőnevekhez hozzárendeltük a beregszászi levéltárból származó iratanyag (125. fond, 6. opisz. 344. iratcsomó) alapján a helyrajzi számokat. Ezt kiegészítettük a NVR területén lévő, a kataszteri térképen szereplő, névvel nem jelölt, de jól elkülöníthető területekkel, határrészekkel, amelyekhez szintén hozzárendeltük a helyrajzi számokat, s ezt táblázatba rendeztük (1. táblázat). Ebben összesen 57 határ-és dúlőnév szerepel. A 2. ábrán 24-es számmal jelölt Kis erdő és két, név nélküli kisebb dúlő a NVR területén van, de az 1865-ös kataszteri térkép szerint már Csomonyához (Csongorhoz) tartozik.

1. táblázat - Table 1

Nagydobrony és a NVR földrajzi neveinek (határ- és dűlőneveinek) adattára

Database of geographical names

(names of pieces of land) of Velyka Dobron and the WRVD

\begin{tabular}{|c|c|c|c|c|c|c|c|}
\hline 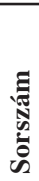 & Határ- és dúlōnév & 矛泀 & $\begin{array}{r}\text { Kata } \\
\text { sz: }\end{array}$ & $\begin{array}{l}\text { zteri } \\
\text { m }\end{array}$ & 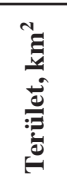 & $\begin{array}{c}\text { Napjainkban jelölt } \\
\text { területtípus }\end{array}$ & $\begin{array}{c}\text { Pesty Frigyes } \\
\text { helységnévtárában } \\
\text { (1864-1865) } \\
\text { szerepló dúlónevek, } \\
\text { azok által } \\
\text { jelölt területtípus }\end{array}$ \\
\hline 1 & Alsó atak közi & 43 & 1564 & 1585 & 0,14 & szántóföld & szántóföld \\
\hline 2 & Általút mente & 40 & 3701 & 3745 & 0,38 & szántóföld, beépített terület & - \\
\hline 3 & Ardó és Sáréger & 47 & 3746 & 3820 & 0,51 & szántó, beépített terület & sástermő, lapos hely \\
\hline 4 & Boholyka & 7 & 2551 & 2556 & 0,24 & szántóföld, legelő & rét \\
\hline 5 & Boholyka alatt & 17 & 1319 & 1410 & 0,30 & beépített terület & rét \\
\hline 6 & Boholyka megi & 8 & 2557 & 2695 & 0,30 & szántóföld, legelő & rét \\
\hline 7 & Csira rekesz & 33 & 3144 & 3146 & 0,04 & erdó & gyümölcsös \\
\hline 8 & Csonkás & 2 & 2065 & 2170 & 0,37 & szántóföld & gyümölcsös \\
\hline 9 & Daranyó mögött & 53 & 3596 & 3700 & 5,10 & szántó & községi erdőrész \\
\hline 10 & Dombos & 27 & 3123 & 3128 & 0,02 & felújuló erdő, írtásrét & gyümölcsös \\
\hline 11 & Égett gorond & 10 & 2938 & 2970 & 0,10 & írtásrét & gyümölcsös \\
\hline 12 & Felső atak közi & 46 & 4140 & 4408 & 0,86 & szántó, beépített terület & szántóföld \\
\hline 13 & Felső erdő & 23 & 3088 & 3149 & 3,66 & erdő & községi erdőrész \\
\hline 14 & Forráshát & 39 & 1442 & 1461 & 0,21 & beépített terület & szántóföld \\
\hline 15 & Géczi rekesz & 28 & 3107 & 3117 & 0,06 & beépített terület, felújuló erdő & - \\
\hline 16 & Haszticsó & 12 & 2846 & 2937 & 0,24 & szántóföld & gyümölcsös \\
\hline 17 & Hóhér gyakra & 36 & 1832 & 1923 & 0,53 & szántóföld, beépített terület & - \\
\hline 18 & Hosszú földek sorja & 38 & 1586 & 1693 & 0,52 & szántóföld, beépített terület & szántóföld \\
\hline 19 & Jázipó & 50 & 3980 & 4076 & 0,40 & szántó & - \\
\hline 20 & Kasláza & 6 & 2038 & 2064 & 0,13 & szántóföld & - \\
\hline 21 & Kerepecz & 49 & 4409 & 4465 & 7,99 & szántó, beépített terület & uradalmi erdőrész \\
\hline 22 & Kerepecz megi & 45 & 1462 & 1543 & 0,25 & szántó, beépített terület & uradalmi erdőrész \\
\hline 23 & Kis erdő (Csomonya) & 24 & 1483 & 1497 & 1,97 & erdő & községi erdőrész \\
\hline 24 & Kis erdő (Nagydobrony) & 13 & 1972 & 2006 & 0,24 & szántóföld & szántóföld \\
\hline 25 & Kisgarb & 20 & 2764 & 2791 & 0,24 & szántóföld, beépített terület & szántóföld \\
\hline 26 & Kiskáricsa & 16 & 1411 & 1441 & 0,41 & beépített terület & rét \\
\hline 27 & Külső rekesz & 15 & 2510 & 2550 & 0,23 & szántóföld & irtásföld, gyümölcsös \\
\hline 28 & Lucska szög & 52 & 4077 & 4139 & 0,37 & szántó & gyümölcsös \\
\hline 29 & Macsoncza köz & 11 & 3071 & 3087 & 1,47 & erdő & uradalmi erdőrész \\
\hline 30 & Magas gorond & 57 & 3604 & 3608 & 0,02 & szántó & - \\
\hline 31 & Meritőhát & 37 & 1694 & 1831 & 0,52 & szántóföld, beépített terület & - \\
\hline 32 & Mosórét & 19 & 2696 & 2729 & 0,11 & szántóföld & rét \\
\hline 33 & Nagygarb & 21 & 2792 & 2845 & 0,50 & szántóföld, beépített terület & szántóföld \\
\hline 34 & Nagygorond & 3 & 2186 & 2509 & 1,15 & szántóföld & gyümölcsös \\
\hline 35 & Nagykáricsa & 14 & 1924 & 1971 & 0,29 & szántóföld & rét \\
\hline 36 & Név nélkül-1 (Kis erdő) & 34 & 1484 & 1489 & 0,08 & erdo" & - \\
\hline 37 & Név nélkül-2 (Kis erdő) & 35 & 1490 & 1497 & 0,05 & erdo” & - \\
\hline 38 & Nyiresszög & 44 & 1544 & 1563 & 0,07 & szántóföld & rét, szántőföld \\
\hline 39 & Pácza láz & 51 & 3480 & 3574 & 0,39 & szántó & - \\
\hline 40 & Pás gorond & 9 & 2971 & 3065 & 0,32 & szántóföld & gyümölcsös \\
\hline 41 & Péter mocsár & 26 & 3118 & 3122 & 0,03 & felújuló erdő, írtásrét & נס \\
\hline
\end{tabular}




\begin{tabular}{|c|c|c|c|c|c|c|c|}
\hline \multirow{2}{*}{ 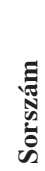 } & \multirow{2}{*}{ Határ- és dúlónév } & \multirow{2}{*}{ 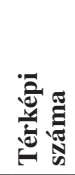 } & \multicolumn{2}{|c|}{$\begin{array}{l}\text { Kataszteri } \\
\text { szám }\end{array}$} & \multirow{2}{*}{ 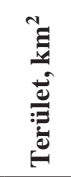 } & \multirow{2}{*}{$\begin{array}{l}\text { Napjainkban jelölt } \\
\text { területtípus }\end{array}$} & \multirow{2}{*}{$\begin{array}{c}\text { Pesty Frigyes } \\
\text { helységnévtárában } \\
\text { (1864-1865) } \\
\text { szerepló dúloónevek, } \\
\text { azok által } \\
\text { jelölt területtípus }\end{array}$} \\
\hline & & & -tól & $-i g$ & & & \\
\hline 42 & Pinte rekesz & 29 & 3129 & 3130 & 0,02 & felújuló erdő, írtásrét & - \\
\hline 43 & Puszta & 31 & 3136 & 3137 & 0,02 & szántóföld & _- \\
\hline 44 & Puszta rekesz & 22 & 3150 & 3245 & 0,51 & szántóföld & szántóföld \\
\hline 45 & Répás & 18 & 2730 & 2763 & 0,27 & szántóföld, lakott terület & - \\
\hline 46 & Róth tagja & 41 & 3246 & 3479 & 1,95 & szántóföld, beépített terület & - \\
\hline 47 & Szanyi irtás & 32 & 3138 & 3143 & 0,04 & szántóföld & - \\
\hline 48 & Szapat & 4 & 3066 & 3070 & 1,72 & erdő, legelő & vizes, lápos hely \\
\hline 49 & Szénégető & 56 & 3609 & 3623 & 0,04 & szántó & kiszáradt patakmeder \\
\hline 50 & Szilas & 48 & 3821 & 3979 & 0,69 & szántó & irtásföld, kaszáló \\
\hline 51 & Szomogya (Szomoga) & 5 & 2007 & 2037 & 0,26 & szántóföld & szántóföld \\
\hline 52 & Szögek erdố & 1 & 2171 & 2185 & 3,18 & erdő & községi erdőrész \\
\hline 53 & Tamás éger & 42 & 4466 & 4476 & 1,24 & szántóföld & mocsaras erdo" \\
\hline 54 & Tarcsa gorond & 54 & 3596 & 3603 & 0,05 & szántó & gyümölcsös \\
\hline 55 & Tarka bikkfa & 25 & 5095 & 3106 & 0,12 & erdő, felújuló erdő, írtásrét & gyümölcsös \\
\hline 56 & Tótok szállása & 30 & 3131 & 3135 & 0,04 & felújuló erdō, írtásrét & \\
\hline 57 & Vörös gorond & 55 & 3575 & 3595 & 0,11 & szántó & gyümölcsös \\
\hline
\end{tabular}

\section{Diszkusszió}

A pontos adattár és térkép elkészítéséhez az általunk összeállított névanyagot összevetettük SEBESTYÉN Zs. (2008a) nagydobronyi helyneveivel. Helynévfelsorolása szintén levéltári anyagok alapján készült: 1863 (125.1.661.K), 1865 (125.1.654), 1908 (125.1.662.K), 1908 (125.1.655), 1908 (125.1.656). A fond száma azonos, de az opisz és az iratcsomó nem egyezik az általunk vizsgálttal. Ezek között van (K-val jelölt) kataszteri térkép, birtokrészleti jegyzőkönyv és határjárásokból származó adat. A helynevek a következőképpen oszlanak meg: 1865-ből 66, 1908-ból először 57, másodszor 41 és végül 14 nevet közöl. Az 1865ből származó nevek közül több nem szerepel a kataszteri térképen: Alsó erdő, Aták hát, Barcsú, Bekeny ádal, Belső szőg, Csorgo hát, Dárnin patak, Estván tava, Fejér rét, Irtás, Malom gorond, Pázá szőg, Remecs hát, Sárdombjo, Szilos mocsár, Tyukszoros nyáros, valamint több esetben a közölt írásmód nem egyezik a térképen megtalálható nevekkel. Ez vélhetően azzal is magyarázható, hogy a birtokrészleti jegyzőkönyvben szereplő megnevezést úgy írták, ahogy hallották: pl. Nyárossziget azonos a Nyiresszöggel. Az 1908-ból (125.1.662.K) származó helységnevekkel, földrajzi nevekkel találtuk a legnagyobb átfedést.

Pesty Frigyes Bereg megye helységnévtárában Nagydobrony községre vonatkozóan találjuk a legtöbb topográfiai földrajzi és dúlőnevet, összesen 113-at. Ebből 11 pataknevet jelöl: Bokolyka pataka, Csonok út pataka, Daranyó patak, Dublutska pataka, Hatracz pataka, Kurta Matsoncza patak, Matsoncza patak, Merdencze pataka, Szamáró, Szetti patak, Zseje patak. Összevetve a kataszteri térképet a Pesty Frigyesnél szereplő dúlőnevekkel kiderül, hogy 102-ből 40 szerepel a kataszteri térképen (1. táblázat). Érdekes, hogy néhány dúlőnév a kataszterin nem szereplők közül a mai napig is ismeretes a falubeliek előtt (pl. Aranyos domb, Cserge domb).

Nagydobrony kataszteri földjeinek teljes területe az 1865-ös térkép alapján 40,71 km² volt. A beépített, lakott részek egyre növekedtek: míg az 1780 -as években csupán 0,09 km² volt, az 1850-esekben 0,28 km², az 1880-asokban 0,47 km², az 1940-esekben (Magyarország katonai felmérése, 1941) $1,36 \mathrm{~km}^{2}$ lett, jelenleg pedig $4,35 \mathrm{~km}^{2}$. Ennek következtében napjainkra 16 dúlő, teljesen elvesztette egykori jellegét, a település belterületének részévé vált. Számos dúlő a II. és a III. katonai felmérés térképén még összefüggő erdőt (pl. Kerepecz) 
vagy mocsaras, ingoványos fás területet (pl. Tamás éger) jelöl (1. táblázat). A folyószabályozás és az extenzív mezőgazdaság következtében ezek a kiterjedt erdók gyors fogyásnak indultak. A fennmaradt dúlőket ma már főként szántók, kisebb részben beépített, lakott településrészek foglalják el.

A Nagydobrony határában valaha hatalmas területeket beborító erdő maradványa ma is megtalálható. Az 1800-as években, a mai Kárpátalját lefedő Ung, Bereg, Ugocsa és Máramaros megyék a történelmi Magyarország jelentős erdős tájai voltak. A Nagydobronyt magába foglaló Ung vármegyét a hetedik legerdősebb vármegyeként tartották számon (FÖlDVÁRY L. 1941). Az I. világháborút lezáró trianoni békeszerződés következtében Magyarország elvesztette erdeinek legértékesebb 84\%-át; az erdősültség 26\%-ról 12\%-ra csökkent és Európa fában egyik legszegényebb országává vált (STANDOVÁR T. 2012). Az 1939 végén visszacsatolt felvidéki területsáv és Kárpátalja erdeinek területére összeállított ideiglenes erdőtörzskönyvek összesített adatait összehasonlítva a Trianont közvetlenül megelőző időkből származó adatokból kiderül, hogy a visszacsatolt felvidéki területsávon mintegy 20 ezer ha $\left(200 \mathrm{~km}^{2}\right)$, Kárpátalján pedig 80 ezer ha $\left(800 \mathrm{~km}^{2}\right)$ erdőt irtottak ki (FÖLDVÁRY L. 1941). Magyarország ennyivel kevesebb erdőt kapott vissza, mint amennyit Trianonnal elveszített. Ebben az időszakban az erdők jellemző fajösszetételét FöLDVÁRY L. (1940) három jellegzetes fajcsoportba sorolja. A síkvidéktől a dombvidéken át az előhegységekig tölgyesek borítják öt fajváltozattal. A középhegységekben és az előhegységek húvösebb, északra néző oldalain, a bükkös állományok következnek, följebb, a közép- és magashegységekben különféle fajösszetételü fenyvesek találhatók.

Nagydobrony az első bécsi döntést követően tehát újra visszakerült Magyarországhoz, Ung megyéhez. Az 1938. évi statisztikai adatok szerint a községnek ebben az időben 1253

kataszteri (katasztrális) hold (721 ha, azaz 7,21 km²) erdőterülete volt (Magyar statisztikai közlemények 1939). Az ezt követő szovjet érában az erdők területe tovább csökkent. Az 1865-ös kataszteri térképen szereplő településhatárokat alapul véve összehasonlítottuk az I., II. és III. katonai felmérés térképein és az 1941-es magyarországi katonai térképen berajzolt, valamint a jelenkori múholdfelvételen látható, a kataszteri határon belül húzódó erdők összterületét. Az erdők kiterjedése jelentősen csökkent: az 1780-as években még közel $30 \mathrm{~km}^{2}$-nyi erdő volt a valamikori kataszteri határokon belül, az 1850-esekben 21, az 1880-asokban 19, az 1940-esekben pedig már csak 10 km². A Google Earth 2019. évi múholdfelvételei szerint ez az erdőterület csupán $8,17 \mathrm{~km}^{2}$. Az Ungvári Állami Erdőgazdaság teljes erdőterülete 2019-ben 17201 ha $\left(172 \mathrm{~km}^{2}\right)$ volt, ebből a Nagydobronyi Erdészethez 2258 ha $\left(22,6 \mathrm{~km}^{2}\right)$ tartozik, amelynek $77 \%$-a $\left(17,4 \mathrm{~km}^{2}\right)$ a Nagydobronyi Vadvédelmi Rezervátum része (Ungvári Állami Erdőgazdaság 2019).

\section{Összefoglalás}

A Kárpátalja negyedik legnépesebb magyar közösségét magába foglaló Nagydobrony község mellett elterülő Nagydobronyi Vadvédelmi Rezervátum a megye harmadik legnagyobb, országos jelentőségú védett rezervátuma. A 18. és 19. századi Magyarország területéről készült I., II. és III. katonai felmérés, az 1865. évi kataszteri térkép, valamint a Kárpátaljai Területi Állami Levéltár beregszászi fiókjában megtalálható iratanyag (125. fond, 6. opisz. 344. iratcsomó), továbbá irodalmi anyagok alapján elvégeztük a település és a védett terület történeti földrajzi helyneveinek (határ- és dúlőneveinek) térinformatikai feldolgozását és térképi ábrázolását. A területről egy 57 elemből álló névtárat állítottunk össze. A település egykori kataszteri határain belül és a Nagydobronyi Vadvédelmi Rezervátum területén húzódó határrészekről és dúlőkkrőlösszefoglaló térképet készítettünk. Elemeztük 
az erdőterület és a földhasználat változásait, aminek következtében napjainkra 16 dúlő, teljesen elvesztette egykori jellegét, a település belterületének részévé vált. Reményeink szerint az elkészült adattár és térképek segítségével megvalósítható a már itt folyó vagy elvégzett kutatások helyének pontosítása, illetve egyértelmúsítése.

\section{KoHUT ERZSÉBET \\ II. Rákóczi Ferenc Kárpátaljai Magyar Főiskola, Biológia és Kémia Tanszék, Beregszász kohut.erzsebet@kmf.org.ua}

\section{BENEDEK ANETT}

II. Rákóczi Ferenc Kárpátaljai Magyar Főiskola, Biológia és Kémia Tanszék, Beregszász benedekanett1@gmail.com

\section{HADNAGY ISTVÁN}

II. Rákóczi Ferenc Kárpátaljai Magyar Főiskola, Biológia és Kémia Tanszék, Beregszász hadnagy.istvan@kmf.org.ua

\section{IRODALOM}

BEREGSZÁSZI A. 1998: Magyar helységnevek Kárpátalján (1988-1995). - In: KACSUR G. (szerk.): Útközben. Kárpátaljai Magyar Kulturális Szövetség, Ungvár. pp. 85-91.

Bíró A. 1993: Kárpátalja településeinek földrajzi nevei. - In: LizANEC, P.-HoRváTH, K. (szerk.): Az Ungvári Hungarológiai Intézet tudományos gyűjiteménye, Intermix Kiadó, Ungvár-Budapest. pp. 134-143.

Bíró F. 1997: Dúlők és dưlőnevek a Körösök vidékén. - Magyar Nyelvtudományi Intézetének Kiadványai 209. pp. 448-54.

BotLiK J.-DupKa Gy. 1993: Magyarlakta települések ezredéve Kárpátalján. - Intermix Kiadó, UngvárBudapest. 209 p.

CsORBA P.-NAGY I.-CsÜLLÖG G. 2018: A földrajzi tájak tipizálása európai kitekintéssel. - Földrajzi Közlemények 142. pp. 272-290. https://doi.org/10.32643/fk.142.4.2

DELI, T.-SÜMEGI,P. 1999: Biogeographical characterisation of Szatmár-Bereg plain based on the mollusc fauna. - In: The Upper Tisa valley: preparatory proposal for Ramsar site designation and an ecological background Hungarian, Romanian, Slovakian and Ukrainian co-operation 4. pp. 471-477.

DEMETER L. 2013: A Szernye-csatorna menti Seleszta kiserdő cönológiai vizsgálata. - Acta Academiae Beregsasiensis 12.pp. 263-271. http://real.mtak.hu/34498/1/Acta_2013_1_Sajat_u.pdf

DEMETER, L. 2016: Biodiversity and Ecosystem Services of Hardwood Floodplain Forests: past present and future from the perspective of local communities in West Ukraine. - In: Roué, M.-MoLnár, Zs. (eds): Knowing our Land and Resources: Indigenous and Local Knowledge of Biodiversity and Ecosystem Services in Europe and Central Asia. Knowledges of Nature, 9, UNESCO: Paris. pp. 6-19.

FARAGÓ I. 2005: A magyar földrajzinév-használat. - Könyvtári figyelő 51. pp. 791-817.

FARAGó I. 2016: Ber, Bere, Berény [,] avagy helynévadás a Kárpát-térségben. - Fríg Kiadó, Budapest. 340 p.

FöLDVÁRY L. 1940: A kárpátaljai kincstári erdők fa faj megoszlása. - Magyar Statisztikai Szemle 3. pp. 5-193.

FÖLDVÁRY L. 1941: Erdőgazdaságunk a keleti és északerdélyi területrészek felszabadulása után. - In: MAGYAR P. (szerk.): Erdészeti Kísérletek 43. pp. 4-71.

GÁBRIEL A. 1991: Hagyományos tájnevek, földrajzi nevek. - Földrajzi Értesítő 40. pp. 161-164.

GÁBRIS GY. 2019: Névföldrajzi kutatások - egy családnév földrajzi és történelmi háttere. - Földrajzi Közlemények 143. pp. 35-54. https://doi.org/10.32643/fk.143.1.4

JuHÁsz D. 1988: A magyar tájnévadás. - Akadémiai Kiadó, Budapest. 109 p.

Kish, R.-ANDRIK, E.-MirUTENKo, V. 2006: Natura 2000 biotopes in the Transcarpathian lowlands [Біотопи Natura 2000 на Закарпатській низовині]. - Мистецька лінія, Ужгород. 64 р.

Kish, R.-Prots, B.-Polyanovskyi A.-Bashta, T.-Danylyk, I. 2009: Prytysianskyi Regional Landscape Park - preservation of the natural heritage of the plains of Transcarpathia [Регіональний ландшафтний парк «Притисянський» - збереження природної спадщини рівнинного Закарпаття]. - Мистецька Лінія, Ужгород. 20 p.

KIss L. 1980: Földrajzi nevek etimológiai szótára, I-II. kötet. - Akadémiai Kiadó, Budapest. 727 p. 
KISS L. 1999: A Kárpát-medence régi helynevei. - In: KIss L. (szerk.): Történeti vizsgálatok a földrajzi nevek körében. Pázmány Péter Katolikus Egyetem, Bölcsészettudományi Kar, Piliscsaba. 355 p.

KMÁAÖTESZ 2020: Kárpátalja környezeti monitoring rendszere [Система моніторингу довкілля Закарпатської області]. - Kárpátaljai Megyei Állami Adminisztráció Ökológiai és Természeti Erőforrások Szakosztálya [Департамент екології та природних ресурсів Закарпатської облдержадміністрації]. http://ecozakarpat.net.ua

Koнut E. 2013: A Sirynga josikea Jaq. fil. ex Rchb. és a Leucojum aestivum L. kárpátaljai természetes állományainak felmérése és in vitro szaporítása. - Doktori (PhD-) értekezés. Corvinus Egyetem, Budapest.

Kohut E.-HöHn M.-JÁmborné Benczúr E. 2006: A Masonca mocsárrét botanikai vizsgálata. - Acta Beregsasiensis 5. pp.157-167.

Kohut E.-HöHn M.-FülöP M.-Kopor Z.-LjubKa T.-MolnáR F.-TAKÁcs G. 2017: Előzetes eredmények a tavaszi tőzike (Leucojum vernum L.) populációjának állapotáról a Peresben. - Limes 14. pp. 9-22. http://kmf.uz.ua/wp-content/uploads/2018/02/Limes2018.pdf

Kohut, E.-Kopor, Z.-NAGY, B.-Csoma, Zs.-Hadnagy, I. 2019: Evaluation of morphometric parameters in case of Leucojum vernum L. from the peres forest in Velyka Dobron Wildlife Reserve, Western Ukraine. - Acta Biologica Marisiensis, 2. pp. 26-35. https://doi.org/10.2478/abmj-2019-0008

Kohut, E.-Ördögh, M.-JÁmbor-Benczúr, M.-Máthé, Á. 2007: Results with the establishment of in vitro culture of Leucojum aestivum L. - International Journal of Horticultural Science 13. pp. 67-71.

KolozSVÁRI, I.-DÉVAI, GY.-SzABó, L. J. 2015a: Occurrence pattern analysis of dragonflies (Odonata) on the River Tisza between Vilok and Huszt based on exuviae. - Applied Ecology and Environmental Research 13. pp. 1183-1196. https://doi.org/10.15666/aeer/1304_11831196

KolozsváRI, I.-SzABó, L. J.-DÉVAI Gy. 2015b: Dragonfly assemblages in the upper parts of the River Tisza: a comparison of larval and exuvial data in three channel types. - Acta Zoologica Academiae Scientiarum Hungaricae 61.pp. 189-204. https://doi.org/10.17109/AZH.61.2.189.2015

KovÁcs A. 2008: Magyar személynévkutatás Kárpátalján. - Névtani Értesítő 30. pp. 203-210.

LEHOCZKY T. 1881-1882/1996: Bereg vármegye monográfiája. - Hatodik Síp Alapítvány-Mandátum, BudapestBeregszász. 501 p.

LŐRINCZE L. 1947: Földrajzneveink élete. - Néptudományi Intézet, Budapest. 32 p.

MagurA, T.-KöDÖвöcz, V. 2005: Forests of the Bereg-Plain as Refuges Based on Their Carabid Fauna (Coleoptera: Carabidae). - Acta Phytopathologica et Entomologica Hungarica 40. pp. 367-382. https://doi.org/10.1556/aphyt.40.2005.3-4.18

Magura, T.-KöDöвöcz, V.-TóthméRÉsz, B.-Molnár, T.-Elek, Z.-SzIlágyi, G.-Hegyessy, G. 1997 : Carabid fauna of the Beregi-síkság and its biogeographical relations (Coleoptera Carabidae). - Folia Entomologica Hungarica 58. pp. 73-82.

Magyar statisztikai közlemények 1939: Az 1938. évi Felvidéki nép-, földbirtok- és állatösszeírás. Az 1938. november 2-i Bécsi döntés alapján visszacsatolt területen végrehajtott összeírás eredményei községek szerint. - Magyar Királyi Központi Statisztikai Hivatal, Budapest. 277 p.

Mizser L. 1995: Bereg megye Pesty Frigyes helységnévtárában (1864-1865). - Szabolcs-Szatmár-Bereg Megyei Levéltárának évkönyve 11.pp. 397-491.

Mizser L. 1996: A Latorca-vidék ősvízrajza és ártéri gazdálkodása. - In: FRISNYÁK, S. (szerk.): A Kárpátmedence történeti földrajza, MTA Szabolcs-Szatmár-Bereg Megyei Tudományos Testülete, Bessenyei György Tanárképző Főiskola Földrajz Tanszéke, Nyíregyháza, pp. 321-326.

Mizser L. 2004: Nagydobrony és Zápszony családnevei. - Magyar Nyelvjárások 42. pp. 209-216.

Molnár D. I.-Tóth-Orosz E. 2020: Decentralizáció Kárpátalján. - Hodinka Antal Nyelvészeti Kutatóközpont, II. Rákóczi Ferenc Kárpátaljai Magyar Főiskola.

URL: http://hodinkaintezet.uz.ua/decentralizacio-karpataljan/

MolnÁR D. I. 2014: A kárpátaljai magyar településnevek változása a XX. század folyamán. - In: BEREGSZÁSZI, A.-HiRES-LÁszló, K. (szerk.): Meszelt falakon túl, Születésnapi köszöntőkötet Kótyuk István tiszteletére. II. Rákóczi Ferenc Kárpátaljai Magyar Főiskola, Beregszász. pp. 131-150.

MolnÁR J.-MolnÁR D. I. 2005: Kárpátalja népessége és magyarsága a népszámlálási és népmozgalmi adatok tükrében. - II. RF KMF, PoliPrint, Beregszász-Ungvár. 115 p.

Móga J.-Szabó M.-Mari L.-Borsodi A.-Kéri A.-KnÁB M.-Kiss K.-Iván V. 2014: Természeti és antropogén hatásokra végbemenő tájváltozások vizsgálata a Bakonyban. - Földrajzi Közlemények 138. pp. 89-106. URL: https://www.foldrajzitarsasag.hu/downloads/foldrajzi_kozlemenyek_2014_138_evf_2_szam.pdf

MórICZ K. 1993: Nagydobrony. - Hatodik Síp Alapítvány, Budapest. 351 p.

NovÁK, P.-ZuKAL, D.-VEČEŘA, M.-PÍŠŤKOVÁ, K. 2017: Vegetation of oak-hornbeam, scree and ravine forests at lower altitudes in Transcarpathia, Western Ukraine. - Tuexenia 37. pp. 47-63. https://doi.org/10.14471/2017.37.021

Prots, B. 2010: Floodplain forests of the Transcarpathia (Ukraine): living close to human. - Journal Biological Systems 3. pp. 58-62. 
SEBESTYÉn Zs. 2003: Beregvidéki helységnevek. - Névtani Értesítő 25. pp. 58-63.

SEBESTYÉn Zs. 2008a: Kárpátalja településeinek történeti helynevei a kataszteri térképek és birtokrészleti jegyzőkönyvek alapján. - Bessenyei Könyvkiadó, Nyíregyháza. 236 p.

SEBESTYÉn Zs. 2008b: Növénynevek beregvidéki helységnevekben. - In: P. LaKatos I.-Pethő J. (szerk.): Elméletek és módszerek. Tanulmányok a nyelvtudomány köréből. A Nyíregyházi Fơiiskola Magyar Nyelvészeti Tanszékének kiadványai. Nyíregyháza. pp. 99-108.

SEBESTYÉn Zs. 2010: Bereg Megye helységneveinek etimológiai szótára. - Bessenyei Könyvkiadó, Nyíregyháza. $168 \mathrm{p}$.

SEBESTYÉN Zs. 2015: Szláv helynévképzők kárpátaljai helységnevekben. - In: Korszerű tudomány, korszerú közoktatás: tanulmányok a nyelv- és irodalomtudományok köréből. Nyíregyházi Fiőskola, Nyíregyháza, pp. 75-89.

SeBESTYÉn Zs. 2016a: Kárpátalja víznevei: a Fekete-Tisza völgye. - Acta Beregsasiensis 15. pp. 183-198. http://kmf.uz.ua/wp-content/uploads/2017/01/Acta2016_ff.pdf

SEBESTYÉN Zs. 2016b: Hegynevek és településnevek a Felsô-Tisza vidékén. - Névtani Értesítő 38. pp. 157-170.

Shevera, M.-Protopopova, V.-Tomenchuk, M.-Andrik, E.-Kish, R. 2017: The first in Ukraine official regional list of invasive plant species of Transcarpathia [Перший в Україні офіційний регіональний список інвазійних видів рослин Закарпаття]. - Вісник НАН України, 10. pp. 53-61. https://doi.org/10.15407/visn2017.10.053

STANDOVÁR T. (szerk.) 2012: Erdők a világban, Európában és Magyarországon. - Országos Erdészeti Egyesület, Erdészeti Lapok, 147. (1.) különszám. 36 p.

SZanyi Sz.-Katona, K.-Bernát, N.-Tamási, K.-Molnár, A. 2015a: A Nagydobronyi Vadvédelmi Rezervátum (Kárpátalja, Nyugat Ukrajna) gyepeinek flórájáról. - Tájökológiai Lapok 13. pp. 1-8.

SZANYI, SZ.-NAGY, A.-VARGA, Z. 2015b: Butterfly assemblages in fragmented meadow habitats of the PreCarpathian lowland (Bereg Plain, SW Ukraine). - Applied Ecology and Environmental Research 13. pp. 615-626. https://doi.org/10.15666/aeer/1303_615626

SZANYI SZ.-SZÓ́CS,L.-CSÓKA GY.-VARGA Z. 2015C: A Beregi-sík Noctuoidea (Lepidoptera: Macroheterocera) faunájának állatföldrajzi és ökológiai jellemzése. - Állattani Közlemények 100. pp. 89-100. https://doi.org/10.20331/AllKoz.2015.100.1-2.89

SZANYI, SZ.-NAGY, A.-VARGA, Z. 2016: Comparison of Macroheterocera assemblages of four forests in the Bereg Plain (Hungary, Ukraine). Biologia, Section Zoology 71. pp. 1281-1291. https://doi.org/10.1515/biolog-2016-0154

Ungvári Állami Erdőgazdaság 2019: Ungvári Állami Erdőgazdaság erdőállománya, erdészetek. https://uzh-lishosp.com.ua/napryam/lisokulturne-vyrobnytstvo/

UNGVÁRY R. 2016: Névterek és földrajzinév-tárak. Észrevételek a Magyarország Földrajzinév-tára és a nemzeti földrajzi névtér jövőbeli fejlesztéséről. Tudományos és Múszaki Tájékoztatás 2016/4. pp. 135-157. 